\title{
MENINGKATKAN KEMAMPUAN MAHASISWA PRODI S1 AKUNTANSI DALAM MEMAHAMI BUKU, EBOOK DAN ARTIKEL/JURNAL AKUNTANSI BERBAHASA INGGRIS
}

\author{
Tira Nur Fitria ${ }^{1}$ \\ Yuge Agung Heliawan ${ }^{2}$
}

STIE AAS Surakarta

Email : tiranurfitria@gmailcom ${ }^{1}$ ugtheniceboy@gmailcom ${ }^{2}$

\begin{abstract}
ABSTRAK
Tujuan dari penelitian ini adalah untuk mengetahui tehnik atau metode pengajar (dosen) dalam meningkatkan kemampuan mahasiswa S1 Akuntansi dalam memahami referensi buku ajar, ebook dan artikel/jurnal internasional berbahasa Inggris. Serta untuk meningkatkan kemampuan meningkatkan kemampuan mahasiswa S1 Akuntansi dalam memahami referensi buku ajar, ebook dan artikel/jurnal berbahasa inggris.

Jenis Penelitian yang digunakan adalah deskriptif kualitatif. Sesuai dengan tujuan penelitian ini, maka mahasiswa S1 Akuntansi menjadi sample (subjek) dalam penelitian ini. Metode yang digunakan dalam penelitian ini meliputi tes, observasi, kuosioner, wawancara maupun dokumen. Melalui penelitian ini, diharapkan menjadi bahan referensi bagi para pengajar (dosen) dalam menyampikan materi perkuliahan dengan menggunakan referensi buku ajar, ebook dan artikel/ jurnal berbahasa Inggris.

Hasil penelitian ini menunjukkan bahwa menunjukkan bahwa adanya peningkatan hasil yang dicapai oleh siswa dari setiap proses tindakan yang dilakukan, yaitu dari tindakan pra siklus (tes awal) hingga siklus II. Hal ini dapat dilihat dari peningkatan nilai rat-rata kelas terhadap setiap proses, yaitu hasil belajar mahasiswa dalam memahami teks/bacaan Akuntansi berbahasa Inggris melalui teknik scanning mengalami peningkatan. Dimana pada siklus awal (tes awal) nilai rata-rata yang diperoleh siswa adalah 51,56, mengalami peningkatan pada siklus I menjadi 65,94, sedangkan pada siklus 2 juga mengalami peningkatan menjadi 78,12. Hasil tersebut menunjukan bahwa peningkatan kemampuan membaca melalui teknik scanning dicapai dengan maksimal sesuai dengan yang diharapkan.
\end{abstract}




\section{PENDAHULUAN}

Indonesia merupakan salah satu negara berkembang yang tidak luput dari zaman globalisasi. Dalam menghadapi era tersebut, aspek Sumber Daya Manusia (SDM) terutama mahasiswa-mahasiwi dituntut untuk dapat menguasai salah satu modal dasar persaingan tersebut yang berupa penguasaan bahasa Inggris. Penguasaan bahasa Inggris tidak hanya digunakan sebagai sarana komunikasi dan interaksi dalam lingkungan sehari-hari. Namun, bahasa Inggris digunakan untuk media pembelajaran, diantaranya dalam bentuk buku-buku, ebook mapupun jurnal internasional yang seringkali kita temui diseitar kita misalnya di lingkungan kampus (perpustakaan) serta internet.

Penguasaan bahasa Inggris pada prinsipnya tidak hanya penguasaan terhadap keterampilan berbicara saja, tetapi juga keterampilan membaca, memahami dan menyimak yang merupakan keterampilan yang patut dikuasai oleh mahasiswa dalam mempelajari sesuatu hal. Dari keterampilan berbahasa tersebut, mahasiswa diarahkan untuk dapat meningkatkan penguasaan mahasiswa bahasa Inggris mahasiswa untuk dapat memahami suatu materi pembelajaran dengan baik.

Sebagai salah satu keterampilan berbahasa, membaca dalam artian menyimak atau memahami merupakan keterampilan yang cukup sulit untuk dikuasai oleh mahasiswa. Membaca pada prinsipnya tidak hanya melafalkan symbol atau huruf yang ada di dalam tulisan tetapi juga membaca bertujuan yaitu memahami makna yang terkandung dalam bacaan atau memahami maksud yang penulis tulis dalam tulisannya. Atau dengan kata lain, tujuan membaca adalah berusaha memperoleh maksud dan tujuan serta makna yang terdapat di dalam tulisan yang dapat berupa fakta-fakta, ide-ide, dan perasaan dari buku atau tulisan. Selain itu, tujuan membaca adalah berusaha mendapatkan pesan yang hendak disampaikan oleh penulis.

Oleh karena itu kegiatan membaca tidak hanya membutuhkan kosentrasi terhadap apa yang akan dibaca tetapi juga membutuhkan pemahaman terhadap makna kata, kalimat, dan wacana yang dibaca. Kosentrasi dan pemahaman terhadap bacaan akan menjadikan mahasiswa efektif dalam membaca. Sehubungan dengan itu, supaya mahasiswa mampu memahami bacaan diperlukan berbagai cara atau teknik yang efektif yang dapat menarik minat mahasiswa dalam memahami. kuliah atau materi pembelajaran atau perkuliahan misalnya mata kuliah Akuntansi. Dimana kita tahu, zaman sekarang ini disekitar kita terdapat buku-buku ajar, ebook maupun artikel/jurnal berbahasa Inggris.

Sebagaicontoh, pengajar (dosen) memerlukan berbagai cara atau teknik yang tepat dalam mengajarkan membaca sehingga mahasiswa dapat memahami makna yang terkandung dalam buku, ebook atau artikel/jurnal berbahasa Inggris. Selama ini yang terjadi, dosen belum dapat menggunakan teknik yang tepat dalam memahami buku, ebook ataupun jurnal berbahasa Inggris, sehingga banyak sekalai mahasiswa sulit untuk menyimak/memahami isi bacaan yang telah dibacanya.

Untuk mengatasi kesulitan yang dihadapi oleh mahasiswa dalam membaca pemahaman (reading comprehension) pada buku ajar, ebook dan artikel/jurnal di mata kuliah akuntansi, pengajar (dosen) memerlukan media, teknik atau cara yang 
tepat dalam mengajarkan materi kuliah pada mahasiswa. Dalam setiap langkah aktivitas diharapkan dapat menarik minat mahasiswa karena langkah-langkah yang diterapkan sudah dilakukan secara sistematis sehingga memudahkan mahasiswa dalam memahami.

Buku ajar, ebook dan artikel/jurnar berbahasa Inggris dapat digunakan dengan baik, para dosen perlu menelaah bagianbagian yang ada dalamnya. Penelaahan dan penjelasan singkat tentang isi tersebut akan menimbulkan minat dan perhatian bagi para mahasiswa dan para pembaca untuk memahami apa yang dibacanya. Sehingga mahasiswa dapat menambah informasi dan pengetahuann tidak hanya dari referensi buku ajar, ebook, artikel/jurnal berbahasa Indonesia saja, melainkan mereka dapat juga belajar dan menanmbah informasi, ilmu dan pengetahuan dari berbagai referensi materi perkuliahan berbahasa Inggris.

\section{PEMBAHASAN}

\section{A. Pengertian Akuntansi}

Akuntansi berasal dari kata asing accounting yang artinya bila diterjemahkan ke dalam bahasa indonesia adalah "menghitung atau mempertanggungjawabkan". Akuntansi digunakan di hampir seluruh kegiatan bisnis di seluruh dunia untuk mengambil keputusan sehingga disebut sebagai bahasa bisnis. Akuntansi sangat diperlukan oleh suatu perusahaan, karena dengan akuntansi kegiatan-kegiatan yang mengubah posisi keuangan perusahaan diproses menjadi suatu informasi yang berguna bagi manajemen perusahaan dan pengguna laporan keuangan lainnya.

Akuntansi sangat diperlukan oleh suatu perusahaan, karena dengan akuntansi kegiatan-kegiatan yang mengubah posisi keuangan perusahaan diproses menjadi suatu informasi yang berguna bagi manajemen perusahaan dan pengguna laporan keuangan lainnya. Ada banyak teori dari para ahli atau narasumber yang menjelaskan tentang akuntansi, diantaranya adalah:

Menurut American Insitute of Certified Public Accounting (AICPA) dalam Harahap (2003) mendefinisikan akuntansi sebagai seni pencatatan, penggolongan, dan pengikhtisaran dengan cara tertentu dalam ukuran moneter, transaksi, dan kejadian-kejadian yang umumnya bersifat keuangan termasuk menafsirkan hasil-hasilnya.

Soemarso (2002:3), mengemukakan pengertian bahwa kuntansi adalah proses mengidentifikasikan, mengukur, dan melaporkan informasi ekonomi, untuk memungkinkan adanya penilaian dan keputusan yang jelas dan tegas bagi mereka yang menggunakan informasi tersebut. Sedangkan, Munawir (2007:5), mengartikan akuntansi sebagai berikut:

"Akuntansi adalah seni dari pencatatan, penggolongan, dan peringkasan dari pada peristiwa-peristiwa dan kejadian-kejadian yang setidaktidaknya sebagian bersifat keuangan dengan cara yang setepat-tepatnya dan dengan petunjuk atau dinyatakan dalam uang, serta penafsiran terhadap hal-hal yang timbul dari padanya".

Kamarudin Ahmad (2007: 6), mengemukakan pengertian akuntansi menurut Ralph Estes (1986) adalah aktivitas-aktivitas yang menyediakan informasi biasanya bersifat kuantitatif dan seringkali disajikan dalam satuan moneter, untuk pengambilan keputusan, 
perencanaan, pengendalian sumber daya dan operasi, mengevaluasi prestasi dan pelaporan keuangan kepada para investor, kreditur, instansi yang berwenang serta masyarakat".

Uraian pengertian akuntansi di atas menyimpulkan bahwa akuntansi adalah ilmu yang membahas suatu sistem yang menghasilkan informasi yang berhubungan dengan kejadian-kejadian yang mengubah posisi keuangan perusahaan. Informasi tersebut dapat digunakan sebagai bahan pengambilan keputusan dan tanggung jawab dibidang keuangan.

\section{Buku ajar, Ebook dan Artikel/Jurnal}

\section{a. Buku Ajar}

Mahasiswa membutuhkan bahan informasi dalam kegiatan belajar, informasi pada umumnya lebih mudah ditemukan dalam buku pelajaran tersebut buku juga memiliki keakuratan sebagai bahan informasi. Buku ajar terdiri dari dua kata yaitu buku dan ajar. Menurut Setiawan (dalam Prastowo, 2012:166) "Kamus Besar Bahasa Indonesia yang mendefinisikan buku sebagai lembar kertas yang berjilid, berisi tulisan atau kosong".

Kata yang kedua yaitu ajar merupakan kata dasar dari belajar yang menjelaskan buku sebagai bahan ajar. Menurut Diknas (dalam Prastowo, 2012:166). "Buku sebagai bahan ajar didefinisikan sebagai buku yang berisi suatu ilmu pengetahuan hasil analisis terhadap kurikulum dalam bentuk tertulis". Berdasarkan uraian diatas dapat disimpulkan buku ajar adalah buku pegangan yang digunakan oleh dosen atau guru dan mahasiswa atau siswa berisi materi pelajaran suatu mata kuliah atau pelajaran tertentu.

\section{1) Pentingnya Buku Ajar}

Buku teks pelajaran atau buku ajar hingga saat ini merupakan bahan ajar yang sering digunakan karena mudah mendapatkannya serta memiliki fungsi yang banyak. Menurut Wibowo (2012:XII) menjelaskan, fungsi buku ajar bagi mahasiswa pemula adalah untuk mengenali, mengingat, dan menerapkan keilmuan yang diajarkan. Sedangkan menurut Achmadi (dalam Wibowo, 2012:XII) menjelaskan, bagi mahasiswa lanjut buku ajar berfungsi sebagai bekal melakukan sintesis dan analisis dalam melakukan penelitian. Buku ajar sangat penting karena memiliki kekhasan yang membedakan dengan diktat, modul, monograf atau buku referensi.

Menurut Wibowo (2012:24) menyebutkan, materi naskah buku ajar dewasa ini dapat berisikan hasil penelitian laboratorium, gagasan konseptual berkaitan dengan kritik atau perbaikan, serta kajian dan aplikasi suatu teori yang bertalian dengan ilmu pengetahuan yang diajarkan oleh dosen. Sedangkan menurut Nasution (dalam Prastowo, 2012:169) menyebutkan, fungsi dan tujuan buku teks pelajaran yaitu:

1). Fungsi buku teks pelajaran

a. Sebagai bahan referensi atau bahan rujukan oleh peserta didik.

b. Sebagai bahan evaluasi 
c. Sebagai alat bantu pendidik dalam melaksanakan kurikulum

d. Sebagai salah satu penentu metode atau teknik pengajaran yang akan digunakan pendidik

e. Sebagai sarana untuk peningkatan karier dan jabatan.

2). Tujuan buku teks pelajaran

a. Memudahkan pendidik dalam menyampaikan materi pembelajaran.

b. Memberi kesempatan kepada peserta didik untuk mengulangi pelajaran atau mempelajari pelajaran baru.

c. Menyediakan materi pembelajaran yang menarik bagi peserta didik.

\section{2) Indikator Penggunaan Buku Ajar.}

Indikator penggunaan buku ajar menurut Prastowo (2012: 170-172), beberapa karakteristik buku teks pelajaran atau buku ajar diantaranya:

Secara formal, buku teks pelajaran diterbitkan oleh penerbit tertentu dan memiliki ISBN. Memiliki dua misi utama tentang pengetahuan. Buku ajar dikembangkan oleh penulis dan penerbit buku dengan mengacu pada apa yang sedang diprogramkan oleh Departemen Pendidikan Nasional. Buku teks pelajaran memiliki keuntungan atau fungsi.

\section{b. Ebook}

\section{1) Pengertian Ebook}

E-book adalah singkatan dari Electronic Book atau buku elektronik. E-book tidak lain adalah sebuah bentuk buku yang dapat dibuka secara elektronis melalui komputer. E-book ini berupa file dengan format bermacammacam, Ebook adalah sebuah rangkaian tulisan biasa yang di buat dengan bantuan software microsoft office atau software lain yang sejenis. Setelah rangkaian tulisan tersebut jadi seperti tulisan dalam buku-buku cetak konvensional seperti yang beredar di pasaran.

Menurut Wikipedia, Buku elektronik (disingkat Buku-e atau ebook) atau buku digital adalah versi elektronik dari buku. Jika buku pada umumnya terdiri dari kumpulan kertas yang dapat berisikan teks atau gambar, maka buku elektronik berisikan informasi digital yang juga dapat berwujud teks atau gambar. Dewasa ini buku elektronik diminati karena ukurannya yang kecil bila dibandingkan dengan buku, dan juga umumnya memiliki fitur pencarian, sehingga katakata dalam buku elektronik dapat dengan cepat dicari dan ditemukan. Terdapat berbagai format buku elektronik yang populer, antara lain adalah teks polos, pdf, jpeg, doc lit dan html. Masing-masing format memiliki kelebihan dan kekurangan masingmasing, dan juga bergantung dari alat yang digunakan untuk membaca buku elektronik tersebut.

\section{2) Fungsi E-book}

E-book menjadi media belajar yang populer selama beberapa tahun ini karena pemerintah secara penuh mendukung penggunaan E-book dalam pembelajaran. E-book berperan penting dalam proses pembelajaran karena memiliki keunggulan. Keunggulan dari 
E-book bisa dilihat dari fungsi dan manfaatnya.

Beberapa fungsi E-book sebagai media belajar yaitu dapat meningkatkan produktivitas belajar. Proses pembelajaran tidak lepas kaitannya dengan sumber belajar yang berupa buku-buku bacaan seperti E-book. Ebook juga sebagai referensi yang tidak terbatas, jadi tidak terpaku pada satu sumber belajar. E-book membantu pendidik dalam mengefektifkan dan mengefisienkan waktu pembelajaran. Pendidik repot jika harus membawa banyak buku bacaan dalam bentuk fisiknya yang berat. E-book yang berupa data digital sangat mudah untuk dibawa dalam banyak file, sehingga pendidik tidak kehabisan bahan belajar untuk peserta didik.

\section{c. Artikel dan Jurnal}

\section{1) Pengertian Artikel/Jurnal}

Artikel adalah karangan faktual secara lengkap dengan panjang tertentu yang dibuat untuk dipublikasikan (melalui koran, majalah, buletin, dsb) dan bertujuan menyampaikan gagasan dan fakta yang dapat meyakinkan, mendidik, dan menghibur. Artikel adalah karangan faktual secara lengkap dengan panjang tertentu yang dibuat untuk dipublikasikan (melalui koran, majalah, buletin, dsb) dan bertujuan menyampaikan gagasan dan fakta yang dapat meyakinkan, mendidik, dan menghibur (Wikipedia, 2016). Jurnal adalah terbitan berkala yang berbentuk pamflet berseri berisi bahan yang sangat diminati orang saat diterbitkan.

\section{d. Penelitian Terdahulu}

Pertama, skripsi yang ditulis oleh Puspantini dkk berjudul Peningkatan Kemampuan Peserta Didik Dengan Metode Sustainable Problem Solving Experience Pada Mata Kuliah Akuntansi. Penelitian ini membahas tentang sebuah metode yang dinamakan Sustainable problem solving experience yang digunakan dalam proses pembelajaran akuntansi yang terfokus pada proses berkelanjutan dan saling berhubungan dalam pembukuan keuangan suatu entitas. Dalam metode ini peserta didik akan menangani suatu siklus pembukuan suatu entitas yang telah ditentukan dalam beberapa periode akuntansi, dimana setiap kasus yang diberikan saling terkait dari awal hingga akhir pembelajaran. Tujuan utama metode ini adalah supaya peserta didik mendapatkan sebuah pengalaman dalam mengelola suatu siklus akuntansi perusahaan. Dengan adanya pengalaman yang didapatkan, peserta didik mampu mengenali sejak dini berbagai macam kondisi dan kasus-kasus yang mungkin terjadi dalam suatu entitas. Dapat dikatakan juga bahwa metode ini merupakan praktek pertama dalam akuntansi. Sehingga akan semakin meningkatkan keandalan dan kemampuan dalam pemecahan masalah. Selain itu metode ini dapat membantu peserta didik dalam meningkatkan kemampuan untuk memenuhi tuntutan.

Kedua, skripsi yang ditulis oleh Oktaviana (2015) berjudul Analisis 
Tingkat Pemahaman Mahasiswa Akuntansi terhadap Konsep Dasar Akuntansi. Tujuan penelitian ini adalah untuk menguji perbedaan Pemahaman Konsep Dasar Akuntansi antara mahasiswa yang berasal dari SMK Akuntansi, SMA jurusan IPA, SMA jurusan IPS, dan Madrasah Aliyah. Penelitian dilakukan terhadap 120 mahasiswa S1 akuntansi yang terdaftar sebagai mahasiswa aktif tahun ajaran 2013/2014 dan telah lulus mata kuliah pengantar akuntansi 1 dan 2. Penelitian ini di uji menggunakan uji kruskal wallis untuk mengukur perbedaan pemahaman Konsep Dasar Akuntansi antara mahasiswa yang berasal dari SMK jurusan Akuntansi, SMA jurusan IPA, SMA jurusan IPS dan Madrasah Aliyah. Hasil menunjukkan bahwa terdapat perbedaan signifikan terhadap tingkat pemahaman asset antara mahasiswa yang berasal dari SMK Akuntansi, SMA IPA, SMA IPS dan Madrasah Aliyah (H1). terdapat perbedaan signifikan terhadap tingkat pemahaman liabilitas antara mahasiswa yang berasal dari SMK Akuntansi, SMA IPA, SMA IPS dan Madrasah Aliyah (H2). terdapat perbedaan signifikan terhadap tingkat pemahaman ekuitas antara mahasiswa yang berasal dari SMK Akuntansi, SMA IPA, SMA IPS dan Madrasah Aliyah (H3). terdapat perbedaan signifikan terhadap tingkat pemahaman pendapatan antara mahasiswa yang berasal dari SMK Akuntansi, SMA IPA, SMA IPS dan Madrasah Aliyah (H4). terdapat perbedaan signifikan terhadap tingkat pemahaman beban antara mahasiswa yang berasal dari SMK Akuntansi, SMA IPA, SMA IPS dan Madrasah Aliyah (H5).

Ketiga, skripsi yang ditulis oleh Pujiarti berjudul Upaya Meningkatkan Hasil Belajar Akuntansi Melalui Metode Pembelajaran Tutor Sebaya Pada Siswa Kelas XI IS 4 SMA N 1 Karanganyar Tahun 2010/2011. Tujuan Penelitian ini adalah untuk mengetahui dan mendeskripsikan penggunaan metode pembelajaran tutor sebaya dapat meningkatkan hasil belajar pada mata pelajaran akuntansi untuk siswa kelas XI IS 4 SMA Negeri 1 Karanganyar. Penelitian ini adalah penelitian tindakan kelas (PTK) dengan menggunakan strategi siklus. Subyek penelitian ini adalah siswa kelas XI IS 4 SMA Negeri 1 Karanganyar berjumlah 32 siswa. Obyek penelitian pada penelitian tindakan ini adalah berbagai kegiatan yang terjadi di dalam kelas selama berlangsungnya proses pembelajaran. Penelitian ini dilaksanakan dengan kolaborasi antara peneliti, guru kelas dan melibatkan partisipasi siswa. Teknik pengumpulan data dilakukan dengan tes, observasi, dokumentasi, dan wawancara. Berdasarkan penelitian yang telah dilakukan, dapat disimpulkan bahwa terdapat peningkatan hasil belajar akuntansi siswa melalui penggunaan metode Tutor Sebaya. Hal tersebut terefleksi dari beberapa indikator sebagai berikut: (1) partisipasi siswa dalam diskusi kelas pada saat presentasi menunjukkan peningkatan 28,12\% dari $56,25 \%$ atau 18 siswa pada siklus 
I menjadi 84,37 \% atau 27 siswa. (2) Partisipasi siswa pada diskusi kelompok meningkat sebesar $15,62 \%$ dari $68,75 \%$ pada siklus I menjadi $84,37 \%$ pada siklus II, (3) Dalam ketelitian dan ketepatan menyelesaikan soal meningkat sebesar $21,87 \%$ dari 20 siswa $(63,50 \%)$ menjadi 27 siswa $(84,37 \%)$

Adanya peningkatan pencapaian hasil belajar siswa sebesar $9,38 \%$ dari $78,12 \%$ atau 25 siswa menjadi 87,50\% atau 28 siswa. Peningkatan tersebut terjadi setelah guru melakukan beberapa upaya, antara lain: (1) Penerapan metode Tutor Sebaya, (2) Guru membuat Rencana Pembelajaran terlebih dahulu sebelum mengajar sehingga kegiatan belajar mengajar dapat berlangsung terarah dan terprogram, (4) Guru melakukan evaluasi setelah pelaksanaan pembelajaran untuk meningkatkan hasil belajar berikutnya. Dapat disimpulkan bahwa dengan penerapan metode pembelajaran Tutor Sebaya dapat meningkatkan hasil belajar akuntansi baik dari domain kognitif, afektif maupun psikomotorik.

\section{METODE PENELITIAN}

Jenis penelitian yang digunakan adalah deskriptif kualitatif. Penelitian deskriptif kualitatif adalah penelitian yang mendeskripsikan data apa adanya dan menjelaskan data atau kejadian dengan kalimat-kalimat penjelasan secara kualitatif (Moleong, 2004). Penelitian kualitatif sebagai penelitian yang bermaksud untuk memahami fenomena tentang apa yang dialami oleh subjek penelitian misalnya perilaku, persepsi, motivasi, tindakan, dll., secara holistik, dan dengan cara deskripsi dalam bentuk kata-kata dan bahasa, pada suatu konteks khusus yang alamiah dan dengan memanfaatkan berbagai metode alamiah.

Metode Pengumpulan Data dalam penelitian ini diantaranya:

1. Tes. Tes diberikan di awal (pre-test), tes siklus 1 dan tes siklus 2 untuk mengetahui peningkatan memahamai teks/bacaan mahasiswa sebelum dan setelah dilakukan tindakan.

2. Wawancara. Tehnik wawancara yang digunakan dalam penelitian ini adalah wawancara tidak terstruktur (unstructed interview). Pihak yang akan diinterview adalah pengajar (dosen) dan sejumlah mahasiswa.

3. Observasi. Observasi yang dapat digunakan dalam penelitian ini, yaitu observasi terhadap situasi dan kondisi selama perkuliahan berlangsung. Bisa meliputi observasi pada pengajar (dosen) dan mahasiswa.

4. Dokumen. Bentuk dokumen yang digunakan dalam penelitian ini berupa buku ajar, ebook atau artikel/jurnal berbahasa Inggris.

Proses analisis data penelitian kualitatif yang dilakukan adalah 1) Reduksi data. Mereduksi data berarti merangkum, memilih hal-hal yang pokok, memfokuskan pada halhal yang penting, dicari tema dan polanya. 2) Display data. Menyajikan data, sehingga data yang diperoleh terorganisasikan dan mudah difahami. 3) Conclusion Drawing. Penarikan kesimpulan. Kesimpulan awal yang dikemukakan masih bersifat sementara, dan akan berubah bila tidak ditemukan bukti-bukti yang kuat.

Dalam keabsahan/validasi data peelitian ini menggunakan Triannggulasi. Trianggulasi berarti peneliti mengunakan tehnik 
pengumpulan data yang berbeda-beda untuk mendapatkan data yang berbeda-beda, serta untuk mendapatkan data dari sumber yang sama.

Triangulasi adalah teknik pemeriksaan keabsahan data yang memanfaatkan sesuatu yang lain di luar data itu untuk keperluan pengecekan atau pembanding terhadap data itu. triangulasi sebagai gabungan atau kombinasi berbagai metode yang dipakai untuk mengkaji fenomena yang saling terkait dari sudut pandang dan perspektif yang berbeda. Menurutnya, triangulasi meliputi empat hal, yaitu: (1) triangulasi metode, (2) triangulasi antarpeneliti (jika penelitian dilakukan dengan kelompok), (3) triangulasi sumber data, dan (4) triangulasi teori (Moleong, 2009).

\section{HASIL PENELITIAN}

Sebelum melaksanakan penelitian terkait kemampuan mahasiswa kelas $1 \mathrm{~A}$ prodi $\mathrm{S} 1$ Akuntansi STIE AAS Surakarta dalam memahami isi bacaan, baik yang terdapat didalam buku/ebook ataupun artikel/jurnal penelitian Akuntansi berbahasa Inggris, sejumlah data penelitian didapatkan dari berbagai sumber data.

Pertama, peneliti melakukan observasi awal dan tes awal pada mahasiswa kelas 1A prodi S1 Akuntansi STIE AAS Surakarta, sebelum diadakan tindakan untuk peningkatan membaca dan memahami teks/isi bacaan melalui teknik scanning (memindai). Dalam melaksanakan observasi dan tes awal, peneliti tidak memberikan penjelasan terlebih dahulu mengenai materi yang diberikan kepada mahasiswa, hanya memberikan gambaran sekilas tentang memahami isi teks/bacaan kemudian mahasiswa langsung diberikan sebuah teks/bacaan untuk dibaca dengan tehnik scanning (memindai). Kemudian menuliskan pokok-pokok atau ide/informasi yang terdapat di dalam teks/bacaan tersebsut.

Peneliti menemukan beberapa masalah di saat observasi awal yang terkait tentang situasi dan kondisi mahasiswa di saat pemberian tes awal berlangsung. Di saat siswa mencoba untuk mengerjalan tes, ternyata keaktifan mahasiswa dalam membaca satu teks/bacaan berberbahasa Inggris masih kurang dan rendah. Mahasiswa terlihat malas untuk membaca kalimatkalimat ataupun paragrapf yang cukup panjang, sehingga berdampak pada pemahaman mahasiswa pada satu teks/bacaan yang diberikan.

Setelah melakukan observasi, peneliti memberikan tes awal. Tes awal diberikan kepada 16 mahasiswa 1A prodi S1Akuntansi. Hasil tes awal (pre-test) dalam memahami isi wacana menunjukkan bahwa rata-rata nilai mahasiswa 1A prodi S1Akuntansi adalah 51,56. Rata-rata ini tentunya jauh dari nilai rata-rata yang diharapkan peneliti yaitu stadar nilai yang harus dicapai mahasiswa adalah 70 . Dari 16 mahasiswa yang mengikuti tes awal, hanya ada 2 mahasiswa yang mencapai nilai 70 dan 75 . Sedangkan yang lainnya memiliki nilai dibawah 70 . Oleh karena itu peneliti menggunakan teknik membaca scanning, yaitu salah satu strategi membaca dalam meningkatkan kemampuan mahasiswa dalam memahami isi teks/bacaan.

Setelah melakukan tes awal, peneliti memberikan kuosioner. Pembagian kuosioner diberikan kepada seluruh mahasiswa semester 1A Reguler prodi S1 Akuntansi STIE AAS Surakarta sebanyak 16 mahasiwa. Kuosioner ini berisi 20 soal yang terdiri dari 5 soal tentang pendapat/persepsi tentang bahasa, 3 soal tentang pengalam membaca, dan 12 soal tentang pemahaman membaca. Hasil kuosioner/angket menunjukkan bahwa 
menurut kebanyakan mahasiwa Bahasa Inggris adalah bahasa Universal yang berguna bagi kehidupan, membaca dan memahami teks/bacaan Bahasa Inggris sangat sulit/rumit, teks/bacaan Bahasa Inggris dipenuhi dengan kosakata-kosakata yang sulit, dan perlunya strategi/cara tertentu dalam memahami teks/bacaan Bahasa Inggris. Kebanyakan mahasiswa jarang membaca/memahami teks/bacaan Bahasa Inggris, serta tidak pernah mengunjungiperpustakaan/toko buku untuk mencari teks/bacaan berbahasa Inggris (terkait dengan makul Akuntansi), serta jarang mendownload teks/bacaan Akuntansi berbahasa Inggris untuk mencari daftar istilah Akuntansi berbahasa Inggris. Serta, kebanyakan mahasiswa lebih cepat membaca/memahami teks/bacaan dalam bahasa Indonesia dan hanya membutuhkan waktu yang singkat. Mahasiwa terkadang mencari arti kosakata baru dengan menggunakan alat bantu misalnya kamus Bahasa Indonesi atau sumber internet. Mahasiwa terkadang menyimpulkan si teks/bacaan Bahasa Indonesia dengan bahasa mereka sendiri. Sedangkan dalam memahami teks/bacaan Bahsa Inggris, mahasiswa membaca/memahami teks/bacaan Bahasa Inggris membutuhkan waktuyang relatif lama. Mahasiwa tidak bertanya atau berdiskusi dengan temannya yang sekira lebih memahami tentang Bahasa Inggris. Mahasiswa juga tidak memahami setiap ide pokok dalam teks/bacaan Bahasa Inggris, serta mereka cenderung jarang/tidak menggunakan alat bantu kamus istilah Akuntansi atau sumber internet lainnya jika tidak ada perintah atau kemauan sendiri.

Tahap selanjutnya adalah melakukan interview dengan dosen Akuntansi dan beberapa mahasiswa kelas $1 \mathrm{~A}$ prodi $\mathrm{S} 1$ Akuntansi terkait pemahaman tentang teks/bacaan Akuntansi berbahasa Inggris. Hasil interview menunjukkan bahwa: 1) dalam memahami teks/bacaan berbahasa Inggris terkadang sulit, karena kosakata yang kurang, 2) membaca/memahami teks/bacaan Bahasa Inggris harus teliti dan harus mengerti yang dimaksud. Seta harus berlatih memhamai istilah-istilah terntu (istilah asing Akuntansi), 3) membaca/memahami teks/bacaan sangat sulit dan ribet karena harus tau ejaan yang lebih, dan berbeda dengan bahasa Indonesia, 4) teks/bacaan Bahasa Inggris sulit dan membingungkan kalau belum mengetahui arti dalam Bahasa Inggris, 5) dan terasa sulit karena tidak setiap mahasiswa pandai berbahasa Inggris.

Untuk mencapai hasil pembelajaran sesuai yang diharapkan peneliti, maka masalah-masalah tersebut dicari jalan keluarnya dengan upaya perbaikan dan peningkatan untuk bisa diterapkan pada pembelajaran selanjutnya yaitu, (1) merencanakan pembelajaran yang lebih dipahami oleh mahasiswa, (2) memberikan motivasi kepada mahasiswa yang mengalami kesulitan dengan memberikan soal dan latihan, (3) menjelaskan secara rinci mengenai masalah-masalah yang dilakukan siswa dalam membaca suatu teks/bacaan Akuntansi berbahasa Inggris.

Tindakan-tindakan ini diharapkan dapat meningkatkan kemampuan mahasiswa kelas 1A prodi S1 Akuntansi STIE AAS Surakarta dalam membaca dan memahami isi teks/bacaan Akuntansi berbahasa Inggris. Oleh karena itu, penelitian ini dilanjutkan berdasar siklus 1 dan siklus 2untuk mendapatkan hasil yang maksimal sesuai dengan tujuan penelitian.

Pada hasil penelitian di atas menunjukkan bahwa adanya peningkatan hasil yang dicapai oleh siswa dari setiap proses tindakan yang 
dilakukan, yaitu dari tindakan pra siklus (tes awal) hingga siklus II. Hal ini dapat dilihat dari peningkatan nilai rat-rata kelas terhadap setiap proses, yaitu: (1) pada tindakan tahap awal nilai rata-rata kelas siswa yang dicapai (2) pada tindakan siklus I nilai rata-rata kelas siswa yang mencapai (3) pada tindakan siklus II nilai rata-rata kelas siswa, dan (4) pada tindakan siklus III nilai rata-rata kelas siswa 82. Hasil tersebut menunjukan bahwa peningkatan kemampuan membaca melalui teknik scanning dicapai dengan maksimal sesuai dengan yang diharapkan.

Hasil tes awal (pre-test) dalam memahami isi wacana menunjukkan bahwa rata-rata nilai mahasiswa 1A prodi S1Akuntansi adalah 51,56 . Rata-rata ini tentunya jauh dari nilai rata-rata yang diharapkan peneliti yaitu stadar nilai yang harus dicapai mahasiswa adalah 70 . Dari 16 mahasiswa yang mengikuti tes awal, hanya ada 2 mahasiswa yang mencapai nilai 70 dan 75 . Sedangkan yang lainnya memiliki nilai dibawah 70. Lebih lanjut lagi, ketika diberikan tes awal sebagian besar siswa tampak kebingungan di dalam menjawab tes karena mereka lebih senang diam dan mengobrol dengan temannya.

Pada siklus I berlangsung satu kali pertemuan, di mana pertemuan ini digunakan untuk memperkenalkan metode pembelajaran scanning sebagai salah satu metode untuk mempermudah dalam membaca untuk mencari informasi dalam bacaan dan memberikan tes sebagai akhir siklus. Pada siklus I menunjukan bahwa nilai yang diperoleh masing-masing siswa rata-rata 66. Ini menunjukan nilai rata-rata pemahaman siswa sudah mengalami peningkatan sebesar $4(16 \%)$ dari tes awal. Karena nilai rata-rata siklus I belum memenuhi target, maka penelitian dilanjutkan pada siklus 2 .
Nilai rata-rata di tes siklus 1 ini meningkat dari hasil rata-rata sebelumnya di tes awal yaitu 51,56. Dari 16 mahasiswa yang mengikuti tes siklus 1 , ada 7 mahasiswa yang mencapai nilai diatas 70. Sedangkan yang lainnya masih memiliki nilai dibawah 70 . Sedangkan di tes awal, hanya ada 2 mahasiswa yang mencapai nilai diatas 70 .

Pada siklus 2, pelaksanaan pembelajaran tidak jauh berbeda dengan siklus I yaitu satu kali pertemuan dan dengan mempergunakan pembelajaran scanning. Nilai rata-rata pada siklus 3 ini adalah 78,12. Dari 16 mahasiswa, hampis semua mahasiswa mapu mencapai skor diatas 70. Nilai rata-rata di tes siklus 3 ini cukup meningkat dari hasil nilai rata-rata di tes awal yaitu 51,56 dan nilai rata-rata 65,94 di tes siklus 1. Dari 16 mahasiswa yang mengikuti tes siklus 1 , ada 2 mahasiswa yang mencapai nilai diatas 70 , dan di tes siklus 2 , ada 7 mahasiswa yang mencapai nilai diatas 70.

Pembelajaran peningkatan kemampuan membaca melalui teknik scanning adalah suatu metode yang dapat membimbing siswa untuk meningkatkan kemampuan membaca suatu bacaan untuk mencari informasi. Hal ini dikarenakan siswa diberikan lebih banya kesempatan untuk membaca dan memahami isi bacaan tersebut dengan baik. Jadi, masalah siswa dalam kemampuan membaca melalui teknik scanning diatasi dengan baik. Oleh karena itu, penelitian ini dihentikan sampai siklus 2.

\section{KESIMPULAN}

Pada hasil penelitian di atas menunjukkan bahwa adanya peningkatan hasil yang dicapai oleh siswa dari setiap proses tindakan yang dilakukan, yaitu dari tindakan pra siklus (tes awal) hingga siklus II. Hal ini dapat dilihat dari peningkatan nilai 
rat-rata kelas terhadap setiap proses, yaitu hasil belajar mahasiswa dalam memahami teks/bacaan Akuntansi berbahasa Inggris melalui teknik scanning mengalami peningkatan. Dimana pada siklus awal (tes awal) nilai rata-rata yang diperoleh siswa adalah 51,56, mengalami peningkatan pada siklus I menjadi 65,94, sedangkan pada siklus 2 juga mengalami peningkatan menjadi 78,12. Hasil tersebut menunjukan bahwa peningkatan kemampuan membaca melalui teknik scanning dicapai dengan maksimal sesuai dengan yang diharapkan.

Pembelajaran peningkatan kemampuan membaca melalui teknik scanning adalah suatu metode yang dapat membimbing siswa untuk meningkatkan kemampuan membaca suatu bacaan untuk mencari informasi. Hal ini dikarenakan siswa diberikan lebih banya kesempatan untuk membaca dan memahami isi bacaan tersebut dengan baik. Jadi, masalah siswa dalam kemampuan membaca melalui teknik scanning diatasi dengan baik. Oleh karena itu, penelitian ini dihentikan sampai siklus 2.

\section{DAFTAR PSUTAKA}

Ahmad, Kamarudin. 2007. Akuntansi Manajemen: dasar-dasar konsep biaya dan pengambilan keputusan. Jakarta: PT. Raja Grafindo Persada.

Prastowo, Andi. 2012. Panduan Kreatif Membuat Bahan Ajar Inovatif.

Harahap, Sofyan Safri, 2003. Teori Akuntansi. PT. Raspindo, Jakarta.

Moloeng, Lexy J. 2004. Metode Penelitian Kualitatif. Bandung: Rosdakarya

Munawir. 2007. Analisa Laporan Keuangan. Yogyakarta: Liberty.
Oktaviana. Devi. 2015. Analisis Tingkat Pemahaman Mahasiswa Akuntansi Terhadap Konsep Dasar Akuntansi. Tesis. Universitas Muhammadiyah Jember

Pujiarti, Puput. 2011. Upaya Meningkatkan Hasil Belajar Akuntansi Melalui Metode Pembelajaran Tutor Sebaya Pada Siswa Kelas XI IS 4 SMA N 1 Karanganyar Tahun 2010/2011. Skripsi. Universitas Sebelas Maret.

Puspantini, HA. dkk. Peningkatan Kemampuan Peserta Didik Dengan Metode Sustainable Problem Solving Experience Pada Mata Kuliah Akuntansi. Tesis. Universitas Mulawarman

Soemarso, S.R. 2002. Pengantar Akuntansi. Edisi Kelima. Jakarta: Penerbit Salemba Empat.

Soemarso; 1996; Pengantar Akuntansi II Cetakan ketiga; Jakarta: PT Renika Cipta.

Warren, dkk. 2005. Prinsip-Prinsip Akuntansi. Jakarta: Erlangga

Wibowo. 2012. Manajemen Kinerja. Jakarta: Rajawali Press

http://www.google.com/url?sa=t\&rct=j\&q=kh oirawatidempo.wordpress.com.

http://www.umpalangkaraya.ac.id/dosen/asep solikin/?p=111

http://www.frizedianto.com/definisi-ebookmenurut-para-ahli/

http://www.kompasiana.com/arjun_fatah_ami tha/peran-e-book-dalampembelajaran_550fd753813311b62cb c6800

https://id.wikipedia.org/wiki/Buku_elektronik 
Meningkatkan Kemampuan Mahasiswa Prodi S1 Akuntansi

Dalam Memahami Buku, Ebook Dan Artikel/J urnal

Akuntansi Berbahasa Inggris

ISSN : 1412-629X

http://ismuhafia.blogspot.co.id/2011/12/peneli tian-deskriptif-kualitatif.html

https://nilaknowledge.wordpress.com/2013/06 /07/pentingnya-buku-ajar/

http://vivopasoepati1923.blogspot.co.id/2012/

11/perbedaan-jurnal-dan-artikel.html

https://jelinaangel.wordpress.com/2013/12/06 /akuntansi/

http://akuntanasi.blogspot.co.id/2013/02/akun tansi.html

http://windawidyaningsih.blogspot.co.id/2014 /06/kemampuan-membaca-teksbahasa-inggris.html 